\title{
Petty Criminality, Gender Bias, and Judicial Practice in Nineteenth-Century Europe.
}

Pluskota M. (2018), "Petty Criminality, Gender Bias, and Judicial Practice in Nineteenth-Century Europe, Journal of Social History 51(4): 717-735”- POST-PRINT

Recent studies on gender and crime tend to emphasize the differences in the treatment of men and women by the criminal courts. Historians researching western European criminal justice have proved that in many instances women were treated with more leniency than men. For London, between 1780 and 1820, Peter King has shown that the judges and juries of the Old Bailey were more likely to sentence a male suspect to death than a woman and that acquittal rates were higher for women. ${ }^{1}$ Deirdre Palk, building on King's findings for the same period, has pointed out that gender may also have played a role in the discretion shown by decision-makers when granting a pardon. ${ }^{2}$ Work on female prosecution and sentencing for other countries or cities highlights a similar gender bias towards women: for instance, Renée Martinage and subsequently Virginie Despres have examined the assizes of northern France in the first half of the nineteenth century, noting that when men and women were accused of stealing food, juries were more likely to set a woman free than a man. ${ }^{3}$ Shapiro and Ferguson, both working on the Parisian assizes, have highlighted the indulgence shown by juries and magistrates towards women who performed according to gender norms and emphasized their own status as victims. ${ }^{4}$ For Italy, Mary Gibson shows that, at the end of the nineteenth century, women accused of infanticide and abortion were treated more favorably by the penal code if they carried out the act in order to "save their own honor." Likewise, Dora Dumont has explained that the Bolognese tribunal at the very start of the nineteenth century was not inclined to prosecute women who took part in rural riots. ${ }^{6}$

Similar conclusions were drawn in the Netherlands: Albert Eggens highlights how criminal women from

\footnotetext{
* The author would like to thank the anonymous reviewers for their comments.

${ }^{1}$ Peter King, "Gender, Crime and Justice in Late Eighteenth- and Early Nineteenth-Century England," in Gender and Crime in Modern Europe, eds. Meg Arnot and Cornelie Usborne (London, 1999), 44-75, especially 53-59; Peter King, Crime, Justice, and Discretion in England, 1740-1820 (Oxford, 2000), chap. 3.

${ }^{2}$ Deirdre Palk, Gender, Crime and Judicial Discretion, 1780-1830 (Rochester, N.Y., 2006), 147.

${ }^{3}$ Renée Martinage, Punir le crime, la répression judiciaire depuis le code pénal (Lille, 1989), 38; Virginie Despres, "Femmes et filles envoyées en prison par la cour d'assises du Nord durant la première moitié du XIXe siècle (18221850)," Histoire, Economie \& Société 3 (2005): 417.

${ }^{4}$ Ann-Louise Shapiro, Breaking the Codes, Female Criminality in Fin-de-Siècle Paris (Stanford, 1996), 61-63, 91; Eliza E. Ferguson, Gender and Justice. Violence, Intimacy and Community in Fin-de-Siècle Paris (Baltimore, 2010), 34-35, 156-158.

5 Mary Gibson, "Women's Prisons in Italy: A Problem of Citizenship," Crime, History and Societies 13 (2009): 29; Ilaria Olivieri, "L'infanticidio tra percezione popolare e trattamento giuridico: Prignano 1889," Storicamente 6 (2010): doi:10.1473/stor71.

${ }^{6}$ Dora M. Dumont, "Rural Society and Crowd Action in Bologna, c. 1796 and c. 1831," The Historical Journal 48 (2005): 991.
} 
Drenthe received somewhat lower sentences than men. He accounts for this difference by pointing to the fact that women had a more central role within the family and that men committed more serious crimes. ${ }^{7}$

Opposing views with regard to who benefitted from the magistrates' leniency have also been developed:

Gemma Gagnon, for instance, shows how women culpable of homicide towards their husbands were treated more harshly by Rouen assizes and were not granted the same mitigating circumstances as men. She claims that the practice of double standard prevalent in cases of spousal homicide worked against women. ${ }^{8}$ The current historiography thus points towards a gender bias in the penal system, and particularly in the sentencing of serious crimes. This was sometimes at the women's expense, but usually it worked in their favor: they were more likely to be released or given a lower sentence.

Dissonant voices on the gender bias experienced in the judicial system have been very rare. Godfrey's and Cox's study on the sentencing of men and women in the UK has however opened a new door: their conclusions on female criminality in the second half of the nineteenth century indicate the absence of gender bias in the judicial decisions of the local tribunals. ${ }^{9}$ Other factors than gender, such as the degree of violence or the relation between victim and assailant, had a stronger influence on the final sentence. ${ }^{10} \mathrm{~A}$ quantitative analysis by Farcy on the Dijon correctional court in the nineteenth century highlights similar results: cases involving male or female suspects were dismissed at a similar rate (38.2 percent and 41.6 percent respectively). ${ }^{11}$ A more recent study by van der Heijden and Pluskota underlines the fact that male and female violence in nineteenth-century Dutch cities was prosecuted at a similar level; the correctional courts did not display undue leniency towards women. ${ }^{12}$ These studies have in common the fact that the primary sources are issued from lower - often provincial - courts, and in the case of France and the Netherlands, specifically from the correctional courts, which mostly dealt with petty criminality. Indeed, the

\footnotetext{
${ }^{7}$ Albert Eggens, Van Daad tot Vonnis, Door Drenthe Gepleegde Criminaliteit voor en tijdens de Eerste Wereldoorlog (Drenthe, 2005), 189.

${ }^{8}$ Gemma Gagnon, "L'homicide conjugal et la justice française au XIX e siècle," in Femmes et justice pénale: XIXeXXe siècles, eds. Christine Bard et al. (Rennes, 2002), 147.

${ }^{9}$ Quoted in Barry Godfrey, "A Historical Perspective on Criminal Justice Responses to Female and Male Offending," in Oxford Handbook of Gender, Sex and Crime, eds. Rosemary Gartner and Bill McCarthy (Oxford, 2014), 163; Barry Godfrey, David J. Cox and Stephen Farrall, Criminal Lives: Family Life, Employment, and Offending (Oxford, 2007).

${ }^{10}$ Barry Godfrey, Stephen Farrall and Susanne Karstedt, "Explaining Gendered Sentencing Patterns for Violent Men and Women in the Late-Victorian and Edwardian Period," British Journal of Criminology 45 (2005): 717;

11 Jean-Claude Farcy, "Le Procureur entre l'Ordre Public et les Justiciables: Plaintes, Procès-Verbaux et Poursuites Pénales à Dijon à la fin du XIXe siècle," Crime, Histoire \& Sociétés 9 (2005): Table no. 5, accessed October 2, 2016, doi : $10.4000 / \mathrm{chs} .384$.

${ }^{12}$ Manon van der Heijden and Marion Pluskota, "Leniency versus Toughening? The Prosecution of Male and Female Violence in $19^{\text {th }}$-century Holland," Journal of Social History 49 (2015): 149-167, doi:10.1093/jsh/shv040.
} 
conclusions of studies underlining a gender bias in criminal prosecution have always been based on the archives of the assizes or a high court such as the Old Bailey, which tried the most serious crimes. Researching homicide, for instance, legitimately forces historians to focus on unusual and often extraordinary criminal actions. The premise of research on homicides is therefore biased from the onset as only specific and "uncommon" crimes are being analyzed. As such, conclusions drawn regarding the relation between gender and crime necessarily point towards the unusual, especially as women tend to commit fewer homicides than men. Therefore, conclusions drawn from the assizes cases, although relevant and correct in this specific setting, are based on the analysis of information which had already trickled through two funnels: first, the characteristics of the offense which made it, according to the law and the decision of the public prosecutor, a serious crime and second, through the funnel of identity, which distinguished between men and women. As such, homicide carried out by men becomes the norm and female homicide a particularity. Due to the exceptionality and rarity of the cases, the comparative methodology applied to the study of serious crimes is essentially biased (murders committed by men being the norm) and dissimilarities between male and female criminals are conceived and worded with reason in terms of gender differences.

Historians did not question whether this bias, favorable or unfavorable to the female suspect, was relevant in the context of other, pettier forms of criminality. I argue therefore that focusing only on the records of the assizes has given us a very one-sided history of female prosecution and crime rates in nineteenth-century Western Europe. This article questions the validity of these conclusions when applied to less serious and more common forms of criminality, which are defined as "delinquency" in the penal code or, in other words, as petty criminality. Petty criminality includes simple thefts, some forms of violence, adultery, vagrancy, repeated public drunkenness and certain forms of public disorders. The trial and sentencing of delinquent people followed a different path from that of offenders sent to the assizes: no jury was involved in giving a verdict and the trials were carried out at a much faster pace than in the assizes (from five to twelve cases per day). Taking into account these fundamental differences in the sentencing process legitimizes the need to question the previous conclusions based only on cases involving serious crimes, in which a jury was present. This article adds to our understanding of the historical relationship between gender and crime by developing an approach that neither imposes gender as the primary lens through which to analyze differences in treatment, nor denies the role of gender in its entirety. By providing quantitative 
evidence on the prosecution rate, verdicts and sentencing of men and women in these correctional courts, this article aims to show that the relation between gender and crime should not be understood as a "plus" or "minus"13 but that a combination of different factors led to a much more gender-neutral approach to petty criminality than was previously thought. In a very insightful article, Cedric Le Bodic explains how criminal statistics could have helped emphasize a male-female dichotomy by focusing criminological analysis on the numerical differences between crime rates. It is true that female crime rates were almost continuously lower than male crime rates, but this analytical approach prejudges female criminality because it uses men as the point of comparison and therefore the norm. ${ }^{14}$ However, by focusing on the practices of the correctional courts and those of suspects, victims and witnesses, we can transcend the statistical difference to reach a deeper understanding of a range of decisions that were not continuously defined by gender differences. Tentative explanations for this absence of gender bias will be sought in the analysis of the organization of the correctional court in comparison with the assizes, the absence of a jury and an interested public, the legal and normative definition of the offense committed and the gender-neutral obligation to respect certain social norms.

\section{A Gender-Neutral Approach to Petty Offenses?}

Most of the historiography so far has been based on the analysis of the gender bias in a common law system or on the study of serious crimes tried in the assizes on the continent. Therefore, researching lower, correctional courts such as the tribunal de première instance will fill a gap in our understanding of the impact of gender in a penal setting. The nineteenth century saw the development of the codification of criminal law and of the functioning of the courts. Countries such as France, the Netherlands or Italy implemented the Napoleonic codes (Code d'instruction criminelle and Code pénal) which led to a restructuring of the court system. The penal code was implemented in France in 1810 and in continuity with the codification of French laws since the Revolution. The French penal code puts the individual victim at the center: he needs to be protected, as well as his family, his patrimony and his reputation. ${ }^{15}$ As such the crime,

13 Cédric Le Bodic, "Peut-on penser la violence des femmes sans ontologiser la différence des sexes?" Champ Pénal/Penal Fields 8 (2011): 1, doi:10.4000/champpenal.8092.

${ }^{14}$ Ibid., 5.

${ }^{15}$ Nicole Arnaud-Duc, La Discipline au Quotidien. La Justice Correctionnelle dans la Provence Aixoise du XIX ${ }^{e}$ siècle (Dijon, 1997), 60. 
more than the criminal, became the pivot of the penal code,${ }^{16}$ which explains why gender had little impact in the wording of the law.

Napoleon imposed his legislation on the conquered territories, but the collapse of the Napoleonic Empire did not lead to the demise of the penal code in these regions. By 1813, Napoleon had withdrawn from the northern territories, but the Dutch magistrates agreed in principle with the idea of a penal code. The code transformed the judicial system of the Netherlands from a fragmented system with primarily local courts that handled almost all criminal cases into a centralized system with fewer courts that dealt with specific types of offenses and crimes. ${ }^{17}$ It distinguished between various types of crimes: felony cases (misdaden), misdemeanors (wandbedriven), and less serious offenses (overtreding). The French penal code was used until 1886, when a new code, the Wetboek van Strafrecht, was implemented. The misdemeanors sentenced by the arrondissementsgerecht were then referred to as misdrijven, and could lead to a fine or a jail sentence of up to five years. The former French division into three types of punishable offenses was changed to a simplified system in which overtreding (minor offenses such as drunkenness and reckless behavior) were dealt with by the kantonsgerechten and misdrijven, while more serious crimes such as rape, fights, theft and murder were dealt with by the arrondissementsgerecht.${ }^{18}$ The Gerechtshof, a higher court than the arrondissmentsgerecht, dealt only with appeals while the highest court, the Hoge Raad, was the cassation court whose role was to decide on the legitimacy of lower courts' trials and sentencing. The particularity of the Dutch penal system was the absence of a jury, even before the abolition of the French penal code in 1886. Indeed, as soon as the King came into power, the jury system was abolished, and the judges remained the only decision-makers during a trial. ${ }^{19}$

In Italy, the implementation of a penal code was met with more apprehension: Napoleon imposed the code on the northern Italian states but with his demise as emperor, the restoration of the former political divisions led to certain modifications in the penal code. In Bologna and in the Papal States in general, the

\footnotetext{
${ }^{16}$ Robert Badinter, La Prison Républicaine (Paris, 1992), 81.

${ }^{17}$ Geertrui A. M. van Synghel, Bronnen voor de criminaliteit en strafrechtspleging vanaf 1811 tot heden, Bronnen Commentaren 7 (Den Haag, 2009), 10-11.

18 Ibid., 15.

${ }^{19}$ Eva H. A. van Luyk, "Het Schuldbeginsel in het Nederlandse Strafrecht" (PhD diss., University of Groningen, 2015), 122.
} 
changing of the law from common law to a penal code system was fiercely opposed.$^{20}$ In 1815 , the Pope reintroduced the former system of ius commune, but the influence of Napoleon over the whole peninsula could still be felt: many territories, such as Naples, Piedmont-Sardinia and Tuscany, penned their own codes (civil, commercial, and penal). The Pope eventually followed their example and promulgated a penal code in 1832, the ius commune being applied only in cases which were not covered by the codes. ${ }^{21}$ The Risorgimento brought with it the penal code of Sardinia, implemented in 1861, which was based roughly on the penal code of Napoleon, until 1889, when the first Italian penal code was imposed. As in the French penal code, the legislation was gender-neutral, but the civil status of women was limited by the civil code and by the traditional view of women's position in society. ${ }^{22}$ The most significant features of the 1889 Zanardelli Code were the significant reduction in the severity of punishments and the apparent closure of the discussion on female guilt. Indeed, the classical school, which elaborated the Zanardelli Code, was opposed to the view of the positivist school, which stated that biological traits had an influence on criminal behavior.. ${ }^{23}$ The Zanardelli Code proclaimed that every human being had "coscienza e libertà dei proprii atti," ${ }^{24}$ meaning that everyone had free will and could therefore be held responsible before a court, except in the case of mental disability. This included women, who could not be considered less responsible than men..$^{25}$

While British criminal law remained based on the common law system, in the nineteenth century most western European governments embarked upon a written codification of the penal laws. This change required a redefinition of prosecution practice and of the role of the magistrates and police in preventing and punishing crimes. ${ }^{26}$ Because of the implementation of the penal code and the code of criminal procedure, looking at male and female crime rates in these countries becomes particularly relevant. Both of these codes demanded an egalitarian, non-gendered application of the law. Whereas the civil code, also implemented

\footnotetext{
${ }^{20}$ Mauro Cappelletti, John H. Merryman and Joseph M. Perillo, The Italian Legal System: An Introduction (Stanford, 1967), 44-45.

${ }^{21}$ I Regolamenti penali di Papa Gregorio XVI per lo Stato Pontificio (1832).

22 Sara Delmedico, Breve Studio sulla Condizione Giuridica della Donna nello Stato Pontifico dell'Ottocento (n.p., 2014).

${ }^{23}$ Luigi Lacchè, “Un Code Pénal Pour l’Unité Italienne: le code Zanardelli (1889) - La Genèse, le Débat, le Projet Juridique," 51, http://dx.doi.org/10.5007/2177-7055.2013v35n68p37

${ }^{24}$ Article 46, Zanardelli Code, 1889.

${ }_{25}$ Giuseppina de Giudici, "Il problema dell'imputabilita della donna tra Otto e Novecento," in Donne e Diritti Osservatorio di Storiografia giuridica (2010): 4, accessed September 11, 2015, http://www1.unipa.it/storichedeldiritto/Materiali/DOSSIER/DEGIUDICI_Imputabilita.html.

${ }^{26}$ See, for instance, Albert G. Bosch et al., Twee Eeuwen Openbaar Ministerie (Den Haag, 2011).
} 
under Napoleon, gave a greater role to the male figure of the household and reinforced patriarchal values, ${ }^{27}$ the criminal law and code of criminal procedure did not imply such a gender bias for the most common offenses, against the person and against property. Magistrates were allowed a certain degree of discretion in applying punishments, but ideally it was expected that men and women would be treated fairly equally.

In principle, the penal code remains in its wording gender-neutral, as was the case for common law. Similarly, the granting of mitigating circumstances in both systems was the responsibility of the magistrate and was not gendered per se. For instance, in France, the use of mitigating circumstances, such as minority and mental disability, gave some discretionary powers to officials and to the jury of the assizes. However, in 1832 the legislation was changed and extended to the correctional courts. The judge was not compelled to explain his decision to grant mitigating circumstances or to mention what he considered attenuating circumstances during a trial, even less so in a correctional court, as magistrates were alone in sentencing the suspect. ${ }^{28}$ The consequences of granting mitigating circumstances to a suspect were that the case could be dropped, sent to a lower court, or the punishment could be reduced. ${ }^{29}$ The most common mitigating circumstances were the age of the suspect, whether the crime was a first offense, the criminal's motivations, the absence of premeditation and so on. ${ }^{30}$ In Amsterdam, mitigating circumstances had been written into the code since 1813, but were cancelled in 1886 , with more leeway being given to the judge when choosing a sentence. $^{31}$

Despite the absence of blatant references to gender, some specific offenses in both systems appear gendered on paper or in practice. Rape and sodomy in the British system were gendered in the sense that, according to precedents, only men could be charged with these offenses. ${ }^{32}$ Adultery and infanticide ${ }^{33}$ were

\footnotetext{
${ }^{27}$ Chiara Saraceno, "Women, Family, and the Law, 1750-1942," Journal of Family History 15 (1990): 430. Vincent Gourdon, "Réseaux des Femmes, Réseaux de Femmes. Le Cas du Témoignage au Mariage Civil au XIXe siècle dans les Pays Héritiers du Code Napoléon (France, Pays-Bas, Belgique)," Annales de Démographie Historique 112 (2006): 36.

28 https://criminocorpus.org/fr/reperes/legislation/textes-juridiques-lois-decre/textes-juridiques-relatifs-la-recidive/28avril-1832-loi-contenant-des-modifications-au-code-penal-et-au-code-dinstruction-criminelle/, accessed October 4, 2016.

${ }^{29}$ Émilie Délivré and Emmanuel Berger, eds., Popular Justice in Europe (18th - 19th centuries) (Bologna, 2014$), 89$. 30

http://ledroitcriminel.free.fr/la_science_criminelle/penalistes/le_proces_penal/le_jugement/sanction/doucet_circ_attenu antes.htm, accessed March 3, 2016.

31 Pauline Schuyt, Verantwoorde Straftoemeting: een Wetenschappelijke Proeve op het Gebied van de Rechtsgeleerdheid (Deventer, 2009), 33.

${ }^{32}$ Daniel J. R. Grey, "Crimes related to Sexuality and Reproduction" in Oxford Handbook of Gender, Sex and Crime, eds. Rosemary Gartner and Bill McCarthy (Oxford, 2014), 229.

${ }^{33}$ Gibson, "Women's Prisons in Italy," 29.
} 
gendered, on paper or in practice, in every country studied: historians have already highlighted how the punishment of adultery was biased; women could be taken to court and was at risk of losing everything (including her freedom) over suspicions whereas tangible evidence and witnesses were needed to start a prosecution against a husband. ${ }^{34}$ A husband was also more likely to be acquitted if he killed his wife after finding her in flagrant délit of adultery. Likewise, even if in the legal text the suspect in an infanticide case is gender neutral, research has shown that only women were accused and sentenced of this crime, that their punishment was often less harsh than in cases of parricide or murder, and that mitigating circumstances could lower the penalty. ${ }^{35}$ But concerning other crimes and misdemeanors, the penal code remained gender neutral in its wording.

\section{Prosecution Rates of Male and Female Suspects}

The following paragraphs focus on the comparison between the three correctional courts in order to examine patterns in prosecution, verdicts or sentencing that might suggest the influence of gender. The crime rates quoted below were drawn from the archives of the ministère public or public prosecutor, who was the magistrate who would record complaints and police reports and decide whether to pursue the suspect or to set him free. He could order an instruction (in other words, an official inquiry) to be carried out or dismiss the case. The principle of legality means that when a case is engaged and instruction of the complaint is being ordered and evidence of a crime is being found, the case has to be tried by a magistrate and will therefore appear in the archives. Thus the influence of gender bias at this stage is much more limited, as the case cannot be dismissed, but it could still become apparent in the outcome of the trial. If gender had a real influence on prosecution patterns, then it should be visible in the pattern of acquittals and the type of punishments imposed.

Male and Female Crime Rates in European cities, 1817-1813.

Table 1. Female crime rates in \%, 1817-1913

\begin{tabular}{|l|l|l|l|}
\hline & Amsterdam & Le Havre & Bologna \\
\hline
\end{tabular}

34 See for instance: Florence Vatin, “Évolution historique d'une pratique: le passage de l'adultère à l'infidélité," Sociétés 1 (2002): 93.

35 James M. Donovan, “Infanticide and the Juries in France, 1825-1913,” Journal of Family History 16 (1991): 157176. 


\begin{tabular}{|l|l|l|l|}
\hline $\mathbf{1 8 1 7}$ & $15 \%$ & $12 \%$ & $13 \%$ \\
\hline $\mathbf{1 8 2 2}$ & $22 \%$ & $15 \%$ & $11 \%$ \\
\hline $\mathbf{1 8 3 2}$ & $27 \%$ & $14 \%$ & $5 \%(\mathrm{y} .1833)$ \\
\hline $\mathbf{1 8 3 7}$ & $24 \%$ & $21 \%$ &. \\
\hline $\mathbf{1 8 4 2}$ & $25 \%$ & $26 \%$ & $10 \%$ \\
\hline $\mathbf{1 8 4 7}$ & $32 \%$ & $18 \%$ &. \\
\hline $\mathbf{1 8 5 2}$ & $26 \%$ & $18 \%$ & $2 \%(\mathrm{y} .1853)$ \\
\hline $\mathbf{1 8 5 7}$ & $21 \%$ & $24 \%$ &. \\
\hline $\mathbf{1 8 6 2}$ & $25 \%$ & $27 \%$ & $14 \%$ \\
\hline $\mathbf{1 8 6 7}$ & $21 \%$ & $22 \%$ &. \\
\hline $\mathbf{1 8 7 3}$ & $21 \%$ & $17 \%$ & $9 \%$ \\
\hline $\mathbf{1 8 8 3}$ & $14 \%$ & $19 \%$ & $16 \%$ \\
\hline $\mathbf{1 8 9 3}$ & $10 \%$ & $21 \%$ & $15 \%$ \\
\hline $\mathbf{1 9 0 2}$ & $13 \%$ & $15 \%$ & $17 \%$ \\
\hline $\mathbf{1 9 1 3}$ & $11 \%$ & & \\
\hline
\end{tabular}

Sources: Amsterdam Stadsarchief (ASA), 5074.A, Rechtbank van Amsterdam en van de Rechtbank van Eerste Aanleg; Parket van Officieren: Registers van strafzaken, 55, 57,72; Noord-Hollands Archief (NHA), 198,

Arrondissementsrechtbank Amsterdam, Parket van de Officier van Justitie, Registers van strafzaken 845-942; Archives Départementales de Seine-Maritime (ADSM) - Tribunal Correctionnel du Havre 3U2/ 1188-1210 (registers); 3U2/9601034 (judgements); Archivio di Stato di Bologna (ASBO) - Tribunale criminale di prima istanza (1816-1831), then known as Tribunale Civile e Criminale - Serie II, Registri 1-2, 12, 21-22, 41-42; Serie P: random samples (100 cases per year) of trial files for the period before 1893, the date of the first register available.

The data collected in the archives of the correctional courts in Bologna, Le Havre and Amsterdam reveal interesting patterns of nineteenth-century female prosecution. This table includes cases which have been tried by the court and have led to a fine, jail time or hard labor, or which have been dismissed because of a lack of evidence, a lack of crime or the death of the suspect or the victim. In certain cases, also counted as dismissed, the suspect and the victim made their peace, or the victim withdrew his complaint. These data therefore represent only the recorded crime (or delinquency) and do not purport to be an accurate picture of the criminality occurring in each city. These figures were gathered from the registers of the prosecutor's clerk, who received the information through the police and, when these registers were unavailable, through a 
random sampling method of the investigation files in Bologna and of the sentencing files in Le Havre. As such, as accurate a picture as possible was drawn of the prosecution work carried out in each city. ${ }^{36}$ Historians of crime are well aware of the problem of the "dark figure," which has often been used to limit the relevance of statistics. The dark figure of crime represents all the cases that have not been reported or discovered. However, early crime historians came to the conclusions that the dark figure had a limited impact on the long-term trends in criminality: Beattie saw it as a constant over time, while Gatrell and Hadden claimed that data collected over a long period and in a large jurisdiction could prevent local police omissions from coming to the fore. ${ }^{37}$ Following this approach, the data in this table reflect a century-long evolution, and also combine information recorded by various police stations (for instance Amsterdam city had six police stations, but those had no jurisdiction over the countryside, which was however also dealt with by the correctional tribunal). What remains certain is the fact that crime statistics reveal what was deemed relevant by the authorities and in this article, what was more often reported by the police. The common idea that women were more likely to be set free by the police when arrested may have been true when the offense was very mild, however a quick search in the police contraventions registers in Le Havre shows that both men and women were regularly fined for creating disorder in the streets by having out-of-control animals or by throwing rubbish in the open or by stealing small drifting cotton balls from the docks. ${ }^{38}$ Regarding more serious offenses, especially violence, it seems less likely that the police would let women go easily, one reason being that the victim may be asking for reparation and therefore is pushing for trial, or at least presentation in front of a judge. Rebellion against an agent also was an easy way for a policeman to get rid of an annoying citizen. ${ }^{39}$ In general, historians of crime believe that the more serious the crime, the less likely it was to go unreported. ${ }^{40}$ Because this article focuses on the records of the correctional tribunals, where the offenses were relatively serious, it is to be hoped therefore that they were more likely to be reported, whether for a man or a woman.

At the beginning of the period, between 12 percent and 19 percent of the suspects were women, with this rate increasing for each city in the following year, except for Bologna. The continuity and the similarities

\footnotetext{
${ }^{36}$ The following data has been collected in the archives mentioned under Table 1.

${ }^{37}$ Quoted in Michael S. Hindus, 'The Contours of Crime and Justice in Massachusetts and South Carolina, 1767-1878', American Journal of Legal History, 21 (1977): 212-247, 214 n. 3.

${ }^{38}$ Archives Municipales du Havre, I3/1/12.

${ }^{39}$ See Marion Pluskota, Gender and Crime in a European Perspective (Leiden, forthcoming) for a more detailed analysis of the discrepancies between men and women and the types of offenses they committed.

${ }^{40}$ Anne-Marie Kilday, Women and Violent Crime in Enlightenment Scotland (Woodbridge, 2015) 2; 40.
} 
in data for Amsterdam, Le Havre and Bologna are striking. Rates of female prosecution in Amsterdam and Le Havre remained constant (around 20 to 25 percent of the total suspects), whereas in Bologna the rate seemed to increase slightly every year, reaching an average of 15 percent for the second half of the period studied. The exceptionally low rate of two percent in 1852 in Bologna is most likely due to the random sampling method chosen to gather these data, rather than representing a true decrease in the female crime rate. Whereas the rates of some years were calculated based on registers including all of the cases that were reported to the court, the rate for 1852 was based only on a sampling of trial files. In general, it appears that female crime rates in Le Havre oscillate sporadically over the century. Another interesting fact that appears in the data is the drop in the rate of female crime in Amsterdam after 1873, which never exceeded the threshold of 14 percent for the next 40 years studied. This decrease is particularly surprising since a reorganization of the court system occurred in 1877, and the new penal code was not implemented until 1886. No clear changes in the legislation or in the judicial system, which would reveal a change in prosecution practice, could be found to explain this drop in female crime rates from a top-down viewpoint. Similarly, in Bologna the new penal code of 1889, the first to be implemented in the entire Italian territory, did not lead to a modification of the prosecution practice against women: the rate remained constant over the following thirty years.

Patterns of prosecution can be profiled in relation to the concerns of the regional elite and the behavior of local criminals. The two main types of crimes prosecuted throughout the nineteenth century in every city were, unsurprisingly, crimes against property (theft, but also robbery, fraud, embezzlement and damage to property) and crimes against the person (assault, threat, defamation). The prosecution of crimes can be understood as mirroring people's concerns, especially of the elite and the middle-class, over the safety of their goods (and by extension, the potential economic development of the city) and their person. ${ }^{41}$ Reported cases of female violence averaged 33 percent of all female petty criminality recorded in Amsterdam between 1812 and 1886; it reached an average of 27 percent of all male petty criminality for the same period (note the broad span for both genders: between 10 percent and 57 percent of all female petty criminality depending of the year studied, and between 17 percent and 52 percent of all cases for men). In Le Havre, between 1815 and 1903, violence averaged 15 percent of cases involving a woman and 24 percent

${ }^{41}$ King, Crime, Justice, and Discretion, 355-358. 
involving a man. Property crime in comparison accounted for 70 percent of Le Havre female petty criminals and 50 percent of male suspects during the same period. The reclassification of certain crimes in the second half of the nineteenth century in France led to an increase in property crimes being tried in the correctional courts. Indeed, thefts in the field and from an inn, some of the most common forms of theft in the nineteenth century, were reclassified as offenses and were therefore referred to the correctional court instead of the assizes. $^{42}$

If we look in detail at the verdicts and sentences, it appears that the discrepancy between men and women was limited. In Amsterdam, for instance, we know that men and women were convicted at very similar rates: 38 percent of men suspected of assault were found not guilty in the Amsterdam correctional court between 1812 and 1832; 37 percent of suspected women were also found not guilty during the same period. A larger set of data including all cases tried by the correctional court in Amsterdam between 1850 and 1886 shows a very high conviction rate for both men and women (between 78 percent and 97 percent depending on the year) with the difference between men and women reaching a maximum of five percent. In the Bologna samples, the differences in proportion between male and female suspects were higher than in the other two cities but did not follow a clear pattern: for instance, in the years 1823, 1853 and 1883, a higher percentage of women were released than men. But in the years 1815, 1833 and 1845 the reverse is true. In Le Havre, the percentage of prison sentences, dismissals and fines given to men and women were identical: 44 percent, 51-52 percent and 4-5 percent respectively. Research on the types of sentences given to culprits by comparing men and women over the same timespan has remained extremely inconclusive: admittedly men were sentenced to certain punishments more often than women (for instance hard labor in Italy or the galera, a sentence which was never given to women in the samples studied) but both men and women were condemned to prison and to pay fines. At the end of the century in Amsterdam it seems that only married women who had committed a crime with a co-offender could expect leniency with regard to their sentence, which resulted in their being condemned to prison slightly less often.$^{43}$ We do see over the years an increase in the number of prison sentences given (this was expected) but no clear pattern or gender bias emerges regarding the decisions of prosecutors or judges to dismiss cases or send culprits to prison. Thus, it is not

\footnotetext{
${ }^{42}$ Despres, "Femmes et filles," 414-415.

${ }^{43}$ Marion Pluskota, ""Criminal Families" and the Court: Co-Offending in Amsterdam, 1897-1902," The History of the Family 20 (2015): 283.
} 
apparent from the archives that the magistrates were particularly lenient towards women in these three cities.

On the contrary, it seems that the procedure followed a relatively gender-neutral path. The argument claiming that gender had a role in prosecution patterns therefore needs to be revised in relation to the functioning of the correctional courts and penal code: it cannot be said that public prosecutors and judges were more lenient towards women than men in these circumstances.

\section{Judicial Practice and Gender Expectations}

The conjunction of several factors can explain this absence of a gender bias. First, the legal performativity highlighted by historians studying the assizes did not carry the same weight in a correctional court. The public performance executed during a trial in the assizes, which has been highlighted by cultural studies on crime and the law, ${ }^{44}$ did not carry the same significance in a lower, provincial court of justice. Magistrates in charge of the sentencing performed and talked in a way that confirmed masculine and elite gender norms of paternalism. ${ }^{45}$ While the judges tended to deliver a paternalistic discourse to the suspect, the latter took this opportunity to perform according to gender norms, and even sometimes to exaggerate his or her understanding and willingness to conform to these social structures, in an attempt to influence the jury, the judges and the public. ${ }^{46}$ Works on the Old Bailey arrive at similar conclusions: jury members were more inclined to give lighter sentences to women committing a felony if they behaved according to their gender norms, such as being a good mother, showing regret or claiming that stealing due to poverty was better than prostitution. ${ }^{47}$ Thus, as Rowbotham and Stevenson explain, "an individual's public representation on the criminal justice stage (...) provided the baseline parameters for the social negotiation of what constituted justice." ${ }^{48}$ And this aspect of the trial was particularly prevalent in the assizes, where a large public, a jury, attorneys and judges were present to try a suspect. Acting according to gender, class or racial norms became all the more important as the punishment at stake could extend to the death penalty.

\footnotetext{
${ }_{44}^{4}$ Martha M. Umphrey, "Law in Drag: Trials and Legal Performativity," Columbia Journal of Gender and Law 21 (2011): 114-129; Julie S. Peters, "Legal Performance Good and Bad," Law, Culture and Humanities 4 (2008): 179200; Judith Rowbotham and Kim Stevenson, "'For Today in This Arena...', Legal Performativity and Dramatic Convention in the Victorian Criminal Justice System," Journal of Criminal Justice and Popular Culture 14 (2007): 113-141; Floriana Colao, Luigi Lacchè and Claudia Storti, Processo pubblica in Italia tra Otto e Novecento (Bologna, 2008).

${ }^{45}$ Martin J. Wiener, Reconstructing the Criminal, Culture, Law and Policy in England, 1830-1914 (Cambridge, 1990), 66; Rowbotham and Stevenson, "For Today in This Arena," 115.

${ }^{46}$ Umphrey, "Law in Drag," 122-124.

${ }^{47}$ King, "Gender, Crime and Justice," 64-67; Rowbotham and Stevenson, "For Today in This Arena", 124.

${ }^{48}$ Rowbotham and Stevenson, "For today in this arena", 116.
} 
The situation in a correctional court, however, appeared very different. The public prosecutor was the first judiciary official in charge of proceeding with a case: either he accepted that an infraction had been committed or he dismissed the case ${ }^{49}$ The preceding numbers have shown that slightly more women had their cases dismissed at this stage, although not to a level that would suggest a conscious gender bias. From then on, the case was sent to the instruction (i.e. for investigation), to be carried out by an examining magistrate (juge d'instruction) with the help of the judiciary police. If the instruction procedure could not uncover enough evidence against the suspect, the case could be dropped by the prosecutor or the examining magistrate before being tried. ${ }^{50}$ Once the instruction was complete and evidence collected, the suspect was tried before one to three magistrates at the correctional court. Even if most trials for petty criminality (except certain affairs described as too indecent) were open to the public, references in the newspapers were limited to a couple of lines, and the names of the magistrates were very rarely quoted. The pettiness of the offenses committed often limited the interest of the general public and therefore of journalists. ${ }^{51}$ This does not mean that the suspects and officials involved in the trial did not try to enact social norms, but the need to perform according to normative roles may not have been as pressing as it was in the assizes in Paris and London. In addition, another aspect of the work of the correctional court that meant that magistrates were less likely to treat women differently from men was the fact that misdemeanors tried in a correctional court could carry a maximum sentence of five or seven years in prison, depending on the code used. Therefore the magistrates in these courts did not face the same dilemma as the jury in the assizes. A guilty verdict was not going to ruin the integrity of a person or his body, unlike a severe sentence in the assizes which could lead to the gallows or to a long exile to the penal colonies. The temptation for a jury to lower the accusation, as seen in London, or to acquit a woman accused of infanticide to prevent her death was not in question in a correctional court, or at least not to the extent that a life was at stake. ${ }^{52}$

Concerns over the partiality and ignorance of juries have existed in France since the Directory, after the implementation of the jury system during the process of judiciary renewal of $1789-1792 .{ }^{53}$ Juries were

\footnotetext{
${ }^{49}$ Bosch et al. Twee Eeuwen Openbaar Ministerie.

${ }^{50} \mathrm{C}$. Venema and R. Huijbrecht, Inventaris van de archieven van de arrondissementsrechtbanken en de parketten van de officieren van justitie in Zuid-Holland, 1838-1939 (Den Haag, 1993), 30.

${ }^{51}$ Frédéric Chauvaud, "Petites affaires et procès pittoresques. Les tribunaliers et "la correctionnelle" de 1880 à 1940 ," Le Temps des Medias 15 (2010): 58.

${ }^{52}$ Wiener, Reconstructing the Criminal, 58-59.

${ }^{53}$ Emmanuel Berger, "The Criminal Jury in England and France in the Late $18^{\text {th }}$ Century," in Popular Justice in Europe, eds. Émilie Délivré and Emmanuel Berger (Bologna, 2014), 87-88.
} 
criticized by members of the government, who relied more and more often on military courts for fast trials. In 1808, during the discussions on the Criminal Instruction Code, the legislative body was asked if "the institution of the jury should be preserved." A compromise was found: the jury d'accusation was suppressed, while the jury de jugement was kept in the assizes. ${ }^{54}$ The incoherence of certain decisions made by members of the jury continued, however, to plague the government's debates and nourished the columns of Parisian newspapers. ${ }^{55}$ This distrust and the cost linked to the use of the jury system led to a modification of the penal code in 1863. Numerous crimes were re-categorized so that they were tried in the correctional courts, so that the written code would reflect what had already become common in judicial practice. Begging with violence, various forms of false writing, threats, disturbing the peace, molestation, and some forms of qualified thefts became therefore 'délits' instead of crimes. ${ }^{56}$ Certain crimes had, in fact, already been moved to the correctional courts early in the nineteenth century in order to lower the costs and, it is thought, to avoid a jury of civilians who might be too kind or overly influenced by public opinion. Indeed, magistrates and intellectuals had noticed the tendency of juries to acquit suspects at a higher rate than magistrates, and it was one of the criticisms raised against jury trials when implemented during the Revolution in France. ${ }^{57}$ Juries were specifically reproached for their "humane" nature, which meant that they sometimes disregarded the law, preferring to rely only on their "intime conviction" and their "own sense of justice". ${ }^{8}$ In Bologna, the jury system was introduced in the Assizes after the unification and the implementation of the PiedmontSardinian code in every Italian province. Italians had been wary of this system since Napoleon tried to impose it, and it was only in 1848 that the Piedmont-Sardinia government decided to try it out against newspapers accused of publishing articles against the government.$^{59}$ In 1859 the jury system was applied to every assizes trial. Once imposed on Italy after the Risorgimento, the debate on the role and partiality of the jury reached Parliament just fifteen years later, when the involvement of newspapers and "trials by media"

\footnotetext{
${ }^{54}$ Ibid., 87.

55 Elisabeth Claverie, "De la difficulté de faire un citoyen: Les "acquittements scandaleux" du jury dans la France provinciale du début du XIXe siècle," Études rurales 95-96 (1984): 143-166; Evelyne Barbin and Yannick Marec, “Un Laboratoire des Statistiques Sociales: Rouen dans la première moitié du XIXe siècle," Histoire \& Mesure 2 (1987): 43.

56 Jean-Claude Farcy, Les Sources Judiciaires de l'Epoque Contemporaine (XIXe-XXe siècles) (Rosny-sous-Bois, 2007), 150 .

${ }^{57}$ Berger, "The Criminal Jury," 86; James M. Donovan, Juries and the Transformation of Criminal Justice in France in the Nineteenth and Twentieth Centuries (Chapel Hill, 2010), 109.

${ }^{58}$ Ferguson, Gender and Justice, 160-161; Laura Mason, "The "Bosom of Proof": Criminal Justice and the Renewal of Oral Culture during the French Revolution," The Journal of Modern History 76 (2004): 35.

${ }^{59}$ Andrea Bosio, “Criminalità, Giustizia e Ordine Pubblico a Torino nella prima metà dell'Ottocento (1814-61)" $(\mathrm{PhD}$ diss., University of Trento, 2015), 41.
} 
became too great to be condoned by the court. ${ }^{60}$ In the Dutch system, distrust of the jury was so high that it had already been abolished in 1813 , even in the assizes, meaning that a close reading of the legal texts followed by the imposition of a punishment for a crime were the pinnacle for the tribunals. An article published in 1933 by W. A. Bonger, a Dutch sociologist and criminologist, in the Journal of Criminal Law and Criminology reiterated the lack of trust in the jury system: "I may state without fear of contradiction that [the abolition of the verdict by juries] has proven almost completely satisfactory and there is, therefore, no wish to re-enact lay jurisdiction." ${ }^{61}$ This is not to say that judges were always fair in their sentencing, or that a penal code is fairer than a common law system. But the subtleties of the penal code system and the study of the correctional courts' archives give a much better picture of the reality of criminality and its prosecution than the assizes or, as King has already mentioned, the study of only indicted crime. ${ }^{62}$ Issues and concerns regarding the jury system and its partiality have not been limited to countries with a penal code. Juries were mandatory in the English assizes and in the quarter sessions, where less serious crimes, but felonies nonetheless, were tried. ${ }^{63}$ However the discretionary powers of the jury did not escape their contemporaries, ${ }^{64}$ and historians of nineteenth-century criminality in England have pointed out the increasing number of cases being sent to summary courts instead of quarter sessions courts. ${ }^{65}$ The 1848 Summary Jurisdiction Act and subsequent acts, followed the tendency observed on the continent due to the sheer number of offenses that had to be tried: ${ }^{66}$ the duties of the justices of the peace were increased and many more offenses fell under their purview, notably simple larceny without violence. As such, the number of criminal acts tried by juries declined, while the work of the summary courts increased dramatically ${ }^{67} \mathrm{~A}$ quick glance at Parliamentarian papers for nineteenth-century England and Wales reveals that men and women were predominantly sentenced by summary courts rather than by the assizes or quarter sessions. ${ }^{68}$

\footnotetext{
60 Angela Groppi, “Il Teatro della Giustizia. Donne Colpevoli e Opinione Pubblica nell'Italia Liberale," Quaderni Storici 3 (2002): 653.

${ }^{61}$ W. A. Bonger, "Development of the Penal Law in the Netherlands," Journal of Criminal Law and Criminology 24 (1933): 260.

${ }^{62}$ Peter King, Crime and Law in England, 1750-1840: Remaking Justice from the Margins (Cambridge, 2006), 219.

${ }^{63}$ David Bentley, English Criminal Justice in the Nineteenth Century (London, 1998), 89-96.

${ }^{64}$ See for instance: Anthony Musson, "Lay Participation: the Paradox of the Jury," Comparative Legal History 3 (2015): 245-271.

${ }^{65}$ Clive Emsley, Crime and Society in England, 1750-1900 (Oxford, 2005), 29, 207-210.

${ }^{66}$ R. M. Jackson, "The Incidence of Jury Trial during the Past Century," Modern Law Review (1937): 133.

${ }^{67}$ Ibid.,136-137.

${ }^{68}$ For instance: Judicial statistics - 1858, England and Wales. Part I. Police--criminal proceedings--prisons. Part II. Common law--equity--civil and canon law; Command Papers; Accounts and Papers, 1859-Session 1 [2508]. http://ezproxy-prd.bodleian.ox.ac.uk:2175/openurl?url_ver=Z39.88-

2004\&res_dat=xri:hcpp\&rft_dat=xri:hcpp:fulltext:1859-035220, accessed September 15, 2016.
} 
Therefore, it can be speculated that a detailed analysis of misdemeanors tried in London summary courts in the nineteenth century would show that magistrates were less lenient when no jury was present. ${ }^{69}$

Gendered prescriptions in everyday life were not as clear-cut as is often described. It was not only the organization of the court that limited the influence of gender in prosecution and sentencing, witnesses, victims and neighbors appeared to respond to specific practices or behaviors rather than to the gendered identity of the suspect. For instance, Jacobus Willem van Assen and his sister Catharina Margaretha van Assen were arrested in 1892 in Amsterdam. It was 10 o'clock at night, and the drunken Jacobus had an altercation with a man in the street. When the policeman arrived to arrest him, his sister threw her lantern at the police officer in an attempt to prevent the arrest. Jacobus and Catharina were convicted respectively to 15 and 3 days of prison. ${ }^{70}$ In the testimonies collected to build this case, witnesses insisted on the fact that they were both pickpockets (although they were not convicted of this offense), but no one accused Catharina of behaving in an unladylike manner. Likewise, in Bologna in 1913, five women were arrested and condemned for trying to prevent, with violence, threats and insults, cart drivers from delivering construction material to a farm that had been burned down some time previously. They tried to stop them for two hours, saying that they should be ashamed to have ruined so many families. ${ }^{71}$ The women were sentenced to three days of detention and fined 100 liras. Again, their gendered identity was not questioned.

Bad behavior, such as being intoxicated, was vehemently condemned by both officials and neighbors, and no distinction between genders was made when this attitude was denounced. In Ingouville, in the suburbs of Le Havre, the widow Hélie and Jacques Mominot were arrested in 1845 for indecent exposure after being caught by a child having sexual intercourse on the rampart of the town. ${ }^{72}$ The widow claimed that she was being assaulted, but the testimony of the police agent denounced her as a habitual drunkard. It turned out that she had lied about the maltreatment and had in fact fallen while drunk. Similar terms were used to describe, 60 years later, the behavior of Félix Heber: he was suspected of theft, vagrancy and drunkenness, and the information collected by the police confirmed his dubious character. ${ }^{73}$ In both cases, the official who

\footnotetext{
${ }^{69}$ Unfortunately, not many summary courts' archives for nineteenth-century London seem to have survived.

${ }^{70}$ NHA, Arrondissementsrechtbank Amsterdam, 198/610 - 1892.

${ }^{71}$ ASBO, Tribunale Civile e Criminale, 2571 - 1913. 'Chiunque, con violenza o minaccia, restringe o impedisce in qualsiasi modo la libertà dell'industria o del commercio è punito con la detenzione sino a venti mesi e con la multa da lire cento a tremila' Art. 165 - Code Zanardelli.

${ }^{72}$ ADSM, Tribunal Correctionnel du Havre, Dossiers de Procédure, 3U2/1305.

${ }^{73}$ ADSM, Tribunal Correctionnel du Havre, Dossiers de Procédure, 3U2/1318.
} 
wrote the reports used his own formal, normative language to describe suspicious living arrangements or the frequentation of immoral characters, which would reduce the attention paid to gender differences. This may indeed have been the case when the summaries of the final judgments were recorded, summaries that typically appear neutral in their wording, limiting the description to the proven facts. ${ }^{74}$

However, when we compare these official enquiries with the testimonies of the neighbors and/or witnesses about a suspect's behavior, we notice that these people were denouncing attitudes and practices that were essentially ungendered. Being lazy, drunk or squandering money and failing to take care of one's family were commonly disapproved of by neighbors. For instance, respecting one's parents was a given that could not be transgressed: when 18-year-old Jean-André Dourson was questioned in 1845 after being arrested for begging and lying about his injuries, one of the first questions of the commissaire de police mentioned the suspect's father: "Is it not true that one month ago your father took you back in his house, clothed you from head to toe and even found you an apprenticeship?"75 Both his father and his mother refused to take care of him and wished to leave him under the authority of the public prosecutor. In another case in Bologna, two young women were sentenced in 1873 for oziosità and sent to a house of correction to learn a craft. ${ }^{76}$ The fact that they refused to follow the advice and admonitions of their parents is repeated twice in the two-page judgment, reinforcing the parents' central position in the lives of these two women. Criticisms of this nature were recorded in the archives for both men and women, and witnesses emphasized the irregularity or asocial characteristics of the behavior itself and not its gendered nature. In cases of maltreatment of a child, the role of the father and his guilt were underlined in parallel with the mother's behavior. When Felix Sampic and his wife Clémentine were denounced for maltreating their daughter, the neighbors blamed both parents and drew a very bleak picture of their behavior and reputation. ${ }^{77}$ Finally, it should be noticed that positive descriptions, such as being a "kind spirit" and good character, were emphasized to a comparable level for men and women. In 1871 the commissaire of Le Havre received a letter from Calais informing him that a woman suspected of having stolen a gold chain may have been lodging in his city. ${ }^{78}$ The victim finished her letter by begging the commissaire for leniency, as she claimed

\footnotetext{
${ }^{74}$ See for instance ASBO, Tribunale Civile e Penale, serie IV, Sentenze, 34; NHA, 198 Arrondissementsrechtbank Amsterdam, Correctionele vonnissen, 1838-1886, n.1-136.

${ }^{75}$ ADSM, Tribunal Correctionnel du Havre, Dossiers de Procédure, 3U2/1300.

${ }^{76}$ ASBO, Tribunale Civile e Penale, serie IV, Sentenze, 34, n. 3646.

77 ADSM, Tribunal Correctionnel du Havre, Dossiers de Procédure, 3U2/1318

${ }^{78}$ Archives Municipales du Havre (AMH), Police, Serie I1, Carton 8, Liasse 1.
} 
that the suspect's situation, as a poor mother, was the only reason why she stole the chain. When Francesco Borgognogni was sent to the tribunal after a fight with Andrea Bianchini in 1844 just outside Bologna, neighbors and employers hastened to give testimonies of his good character and underlined the provocation he suffered by Andrea before he punched him. ${ }^{79}$

This does not mean that gender has no place in the study of crime but that the influence of gender on daily social practices was moderated by the context in which the action took place. Only certain aspects of the suspects' behavior were gendered: for instance, to avoid the accusation of living in debauchery, women had to conform to the stereotypical stories that corresponded to social norms: Joséphine Igout for instance complained in 1818 against her lover after he maltreated her.$^{80}$ They had been seeing each other for two years and she repeatedly explained that a marriage proposal was on the table: her female neighbors had knowledge of this relationship and did not seem to regard it as unusual or unacceptable, as a promise of marriage had been openly mentioned. ${ }^{81}$ Ruault, her offender, also followed a specific type of discourse to rationalize his actions: he explained that he was madly in love ('trop attaché') and that he had agreed to many a sacrifice for the demoiselle Igout but that in the last two months, he had tried to refrain from seeing her. Unfortunately, he had decided that night, "contrary to his usual behavior"' to have a drink with his coworkers and after that tipple, he walked unintentionally towards Josephine's apartment. Finding a man in her room, he got very upset and started beating her while the other man ran away. In an attempt to justify his deeds, Ruault evoked the stereotype of the drunken man overwhelmed by his emotions. On the other hand, Josephine Igout's testimony reflects a similar performance: she first felt the need to legitimize her relation with Ruault in order to give more weight to her complaint against him. An entirely different case tried in Amsterdam in 1892 reveals a similar awareness of the need for suspects to conform to gender norms: Johanna Bodet was accused of hiding and pawning hand towels stolen by her younger brother who lived and worked at the orphanage. ${ }^{82}$ She claimed that she did not report the theft to the police because she knew that her brother would be evicted from the orphanage and that she would have had to take care of him. She would have had to explain that she lived with a man without being married and did not want people to know about

\footnotetext{
${ }^{79}$ ASBO, Tribunale Civile e Criminale, 1845, Mazzo 65, n. 7678.

${ }^{80}$ ADSM, Tribunal Correctionnel du Havre, Dossiers de Procédure, 3U2/1290.

${ }^{81}$ Georg'ann Cattelona, "Control and Collaboration: The Role of Women in Regulating Female Sexual Behavior in Early Modern Marseille," French Historical Studies, 18 (1993): 13-33.

${ }^{82}$ NHA, Arrondissementsrechtbank Amsterdam, 198/610 - 1892.
} 
her situation. Although her story seems unreliable, by mentioning her living situation as a reason why she did not want to have officials involved, she revealed her understanding of what could be considered acceptable and what was not. Thus, the issue of gender identity arose in certain situations, but, much more often than in the assizes, the offense and the behavior of the suspect were considered in a gender-neutral manner.

\section{$\underline{\text { Conclusion }}$}

This article questioned the assumption that gender had a strong impact on the prosecution patterns in nineteenth-century western Europe. Whereas this theory has been proven accurate in a common law setting or when juries were involved, its relevance in a penal code system and, specifically, in correctional courts has never been questioned in depth. Evidence from judicial archives in three different cities, Bologna, Amsterdam and Le Havre, were collected to determine how influential the work of the public prosecutors and the judges was on gender differences in crime rates. The figures drawn from these archives represent, with the exception of a few sample years, the percentage of men and women reported as suspects to the public prosecutors, who were at the point of entry of the judicial system. Once the complaint was recorded by the court clerk, the public prosecutors were in charge of deciding whether the case should be pursued or not and whether an official inquiry should be ordered. Although gender bias might have been expected from the prosecutor's office, it appears that the number of cases involving female suspects being dismissed at this stage did not exceed the number of dismissed cases involving male suspects to any significant level (the difference could reach three percent but if we consider absolute numbers, more male suspects were allowed to go free than female suspects). An analysis of the verdicts in the different courts over the century came to a similar result: the data representing men and women turned out to be very similar. However, we do see over the century an improvement in the investigation techniques, which led to a higher rate of guilty verdicts. Finally, some discrepancies have been noticed in the types of punishments: for instance, in Bologna, men were sentenced to prison and hard labor in a penal colony, whereas very few women were condemned to this combined sentence. Likewise, in Amsterdam it appears that married women were less often sentenced to prison than single women, possibly highlighting their essential role within the household. However, overall, no blatant positive or negative discrimination towards one or the other gender could be found in the work of these three correctional courts. 
Challenging the common assumption that gender shaped prosecution patterns, this article explains the reasons why gender bias was less prevalent in correctional courts than in courts using a jury system, such as the assizes or the quarter sessions. First, the high number of correctional court cases meant that only a limited amount of time could be given to each case. Even though the tribunal was open to the public, the verdict and sentencing were given much more quickly than in the assizes. The use of the court as a stage to perform publicly legitimized gender norms did not occur in a correctional court: the interrogations and examinations took place in private and not before the public. What occurred during the trial was only a reiteration of the discussions held during the investigation. Little opportunity was given to the suspect to change his version or add any information, and the verdict and sentencing were usually reached rapidly. As such, the male or female suspect had little chance to insist upon or play with the gender norms which would have influenced his position in the assizes. Of course, the suspects were not the only people in the court who could emphasize and reaffirm commonly accepted gender norms. In the assizes in Paris, the peremptory discourse given by the judges or public prosecutor to the suspect was delivered in front of a much larger public than in the Le Havre, Bologna or even Amsterdam correctional courts, especially if the case involved a woman. Besides the general public, journalists could also be present at the assizes, as well as members of the elite who attended assizes trials as a distraction. This means that the speeches and interjections of the judges could be heard, printed and repeated outside the walls of the court and by other members of the Parisian elite. The assizes gradually became quasi-theatrical performances of the moral order and the roles and importance of the journalists and the public, especially in Paris, must not be underestimated in the judicial process. Trials sent to the Le Havre, Bologna or Amsterdam correctional courts however covered only a few lines in the provincial newspapers, the names of the judge, suspect or victim were more often than not absent from the weekly publications. In addition to the lack of interest by the public and journalists in petty criminality, the fact that the suspects were tried by law officials and not by a jury also limited their need to emphasize their compliance with gender norms: indeed, what was highlighted by Peter King in London was the leniency of the jury in their verdicts against women. In a correctional court, however, the jury was absent and only magistrates had the right to give a verdict and sentence a suspect. This does not mean that every magistrate in charge over the century in these different courts always followed the legal codes and carried out his duties in accordance with the gender-neutral wording of the law. However, this article has proven that there is no pattern suggesting systemic gender bias by the magistrates in their 
sentencing on petty criminality. Finally, this article also encourages historians to put the notion of gender into perspective: gender expectations did exist and were sometimes reinforced by the authorities (for instance, regarding the duty of women as mothers), but they shaped both men's and women's lives and did not always lead to a positive or negative gender bias. 